Електронне "Державне управління: удосконалення та розвиток" включено до переліку наукових фахових видань України з питань державного управління

(Наказ Міністерства освіти і науки України від 22.12.2016 № 1604) www.dy.nayka.com.ua | № 82019 p. | 29.08.2019

DOI: $\underline{10.32702 / 2307-2156-2019.8 .24}$

УДК 351:628.1:331](477)

\title{
I. I. Крилова,
}

кандидат юридичних наук, докторант

Наџіональної академії державного управління при Президентові України, Київ, Україна

ORCID: 0000-0003-2667-9245

\section{ЕФЕКТИВНІСТЬ УПРАВЛІННЯ У СФЕРІ ВОДОПОСТАЧАННЯ ТА ВОДОВІДВЕДЕННЯ. ОСНОВНІ ПРИНЦИПИ}

\author{
I. I. Krylova \\ Candidate of Law, Doctoral student of National Academy for Public Administration under the \\ President of Ukraine, Kyiv, Ukraine
}

\section{EFFECTIVE MANAGEMENT BY WATER SUPPLY AND WASTEWATER ENTERPRISES. BASIC PRINCIPLES}

В иій статті аналізується питання ефективності управління у сфері водопостачання та водовідведення. Підприємства водопостачання та водовідведення працюють в умовах наявності зовнішніх інституиійних проблем галузі, щзо безпосередньо впливають на їх ефективність. Це спонукає керівників підприємств до постійного пошуку резервів та шляхів підвищення ефективності використання у прочесі своєї діяльності всіх ресурсів. Власних коштів ледь вистачає на підтримку функиіонування підприємств водопостачання та водовідведення, а кредитні чи грантові кошти надаються за умови, щуо реформи, які забезпечуються ними, призведуть до «ефективного управління», «хорошого урядування» краӥни, міста, сфери та підприємств иієєі сфери. Автор статті аналізує поняття "Хороше урядування», «ефективне управління» та його визначення у вітчизняній науковій літературі та напращюваннях міжнародних фінансових та водних організаџій. Автор вказує на відсутність принципів чи стандартів хорошого та ефективного управління у вітчизняних нормативних документах $i$ практиці, окрім як показників ефективного використання комунального майна. Автор розглядає принципи хорошого врядування, зазначені міжнародними організаціями; принципи хорошого водного врядування, розроблені Організацією економічного співробітництва та розвитку, атрибути та принципи ефективного управління підприємствами водопостачання та водовідведення, розроблені американськими та європейськими підприємствами - лідерами у сфері послуг $з$ водопостачання та водовідведення. Стаття може бути иікавою для дослідників питання ефективного управління підприємствами комунальних послуг та керівників підприємств водопостачання та водовідведенням, які можуть впроваджувати міжнародні атрибути та принциии в своїй діяльності.

This article analyzes the issues of efficiency in the management of water supply and wastewater. Water supply and wastewater companies operate in the presence of external institutional problems of the industry, which directly affect their efficiency. This encourages business leaders to constantly 
search for reserves and ways to improve the efficiency of use of all resources in their operations. Own funds are hardly sufficient to support the functioning of water supply and wastewater companies, and credit or grant funds are provided that the reforms they provide will lead to "effective management", "good governance" of the country, city, sphere and enterprises in this field. The author analyzes the concepts of "Good Governance", "Effective Governance" and its definition in the domestic scientific literature and the developments of international financial and water organizations. The author points to the absence of principles or standards of good and effective management in national regulations and practice, except as indicators of efficient use of communal property. The author reviews the principles of good governance as outlined by international organizations; principles of good water governance, developed by the Organization for Economic Co-operation and Development, attributes and principles for the effective management of water supply and wastewater companies, developed by US and European leaders in the field of water supply and wastewater services. The efficiency of managing and organizing the operation of a water supply and wastewater company can be assessed by determining appropriate performance indicators. Given the lack of national standards and principles for the effective management of water supply and wastewater companies, in addition to the indicators of efficiency of municipal property and profit, the attributes and principles of effective management developed by leading international water associations can be taken into account. The article may be of interest to researchers on the effective management of utilities and water supply and wastewater managers who can implement international attributes and principles in their activities.

Ключові слова: водопостачання та водовідведення; управління; менеджмент; ефективне управління; хороше врядування.

Key words: water supply and wastewater; administration; management; effective management; good governance.

Постановка наукової проблеми та її значення. За останні десять років терміни «хороше управління», «хороше урядування» та «ефективне управління» все частіше використовуються в різній літературі $з$ розвитку країни та сфер господарства країни. Проте, відсутність чітких стандартів та принципів належного ефективного управління $є$ серйозною перешкодою для його впровадження, в тому числі, і у сфері водопостачання та водовідведення. Важливість дослідження цього питання підсилюється тим, що міжнародні фінансові інститути часто визначають «ефективне управління» та «хороше урядування» одним з критеріїв їх допомоги і кредитів у сфері водопостачання та водовідведення. Тобто, кредитні чи грантові кошти надаються за умови, що реформи, які забезпечуються ними, призведуть до «ефективного управління», «хорошого урядування» країни, міста, сфери та підприємств цієї сфери.

Аналіз останніх досліджень. У ході дослідження обраної теми проаналізовано наукові праці таких вітчизняних та зарубіжних науковців, як: І. Коврижних [8], В. Кравченко [9], М. Мескон [10], I. Павленко [11], С. Прижвара [12], О. Рац [15], Я. Рудьман [16], В. Рульєв [17], Т. Сугак [18], С. Федулова [19], В. Шатун [21], О. Щеглова [22] та ін., а також міжнародних фінансових та водних організацій.

Мета статті. Основною метою статті є з'ясування вітчизняних та іноземних підходів та принципів ефективного управління у сфері водопостачання та водовідведення.

Виклад основного матеріалу. Особливість сучасного управління (менеджменту) полягає в його спрямованості на забезпечення раціонального ведення господарства в умовах дефіциту ресурсів і досягнення високих кінцевих результатів 3 мінімальними витратами, оптимальною адаптацією організації до нових ринкових умов. Основні принципи управління, вироблені на початку XX сторіччя, доповнилися відповідними духу і вимогам часу ефективними принципами діяльності підприємств і фірм: 1) пріоритет споживача, надійність, швидкість і зручність обслуговування; 2) висока якість товарів і послуг, наслідування лідерам; 3) доступні широким масам покупців ціни; 4) дотримання моральних норм; 5) допомога іншим підприємцям у досягненні успіху; 6) використання конкуренції (монополія - ворог високої продуктивності і якості); 7) орієнтація на перспективу, підвищення стандартів і розширення сфери діяльності; - орієнтація на кінцеві результати діяльності; 8) прагнення до нововведень, постійна підтримка духу новаторства; 9) опора на об'єктивні закони і реальність ринкових ситуацій; 10) рішення нових проблем новими методами, виправлення помилок; 11) орієнтація на індивідуальне споживання і загальнолюдські інтереси; 12) концентрація діяльності на пріоритетних програмах; 13) розширення і поглиблення зв'язків фірми з зовнішнім оточенням; 14) постійний пошук альтернативних варіантів діяльності фірми [21, с.23]. 
Хоча поняття «ефективне управління» включає в себе різні види управління від державного, місцевого урядування до управління підприємством, більшість українських дослідників зводять його саме до управління підприємствами певної галузі. Стосовно визначення ефективності діяльності та управління підприємств різних галузей народного господарства, а також її основних критеріїв, було проведено достатньо наукових досліджень та надано багато визначень. Зокрема, Рудьман Я. зазначає, що ефективність управління - це категорія, яка відображає вклад управлінської діяльності в підсумковий результат роботи підприємства [16]; Коврижних I. вважає, що ефективність управління визначається шляхом зіставлення результатів управління і ресурсів, які витрачено на процес управління [8, с. 12]; Мескон М., Альберт М. і Хедоур І. зазначають, що ефективність, як правило, піддається кількісній оцінці, оскільки і вводяться і виводяться ресурси можна уявити в чіткому грошовому виразі [10]; Павленко I. зазначає, що ефективність управління - це комплексна оцінка кінцевих результатів використання трудових, матеріальних, інформаційних та фінансових ресурсів підприємства у виробництві товарів та наданні послуг за певний термін [11]; Рац І. під ефективністю управління визначає комплексну характеристику, яка відображає ступінь використання ресурсних витрат, спроможність досягати поставлених цілей та здатність до стійкої життєдіяльності у конкурентному ринковому середовищі [15]; Щеглова О. вважає, що ефективність управління - це здатність керуючої системи забезпечувати реалізацію заданих (тактичних і стратегічних) цілей підприємства, представлених відповідними якісними і кількісними показниками, що відображають результативність використання задіяних ресурсів (в тому числі, і витрат на управління) і ринкові характеристики бізнесу (його успішність і ділову активність), які розглядаються як оціночних критеріїв [22]. За позицією Філіппової О.С. ефективність діяльності виробничих підприємств визначається як відносний показник, що дозволяє встановити «вартість» досягнутого результату за рахунок його співставлення з використаним для цього ресурсами або загальною сумою витрат. Ефективність діяльності невиробничих підприємств визначається ступенем досягнення поставлених цілей або реалізації запланованої діяльності. Відмінність в трактуванні ефективності діяльності для вказаних об'єктів обумовлює існування певної розбіжності в критеріях їх визначення. Під ефективністю діяльності підприємств житлово-комунального господарства, дослідник пропонує визначати позитивну результативність діяльності підприємств, що характеризується ступенем своєчасності та повноти задоволення необхідних для нормальної життєдіяльності потреб населення відповідно до встановлених норм та стандартів на основі підвищення економічних результатів свого господарювання при одночасному дотримані принципів економічності та рентабельності поточної діяльності зазначених суб'єктів [20, с. 135].

Поняття ефективності, по відношенню до комунальних підприємств відрізняється від поняття економічної ефективності, яке застосовується під час оцінки діяльності приватних підприємств. Зазвичай, ефективність діяльності приватних підприємств оцінюють за комерційними показниками, такими як, прибутковість та рентабельність майна чи бізнесу у цілому. По відношенню ж до об'єктів комунальної власності, оцінюють не лише економічну ефективність, а й соціальну, тобто визначення ефективності діяльності комунального підприємства 3 точки зору інтересів відповідної територіальної громади, яка $\epsilon$ власником його активів [7; 18].

Сугак Т., досліджуючи ефективність управління підприємствами водопостачання та водовідведення, пропонує застосовуватися економічні, соціальні та технічні показники. До економічних показників, в тому числі досягнення беззбитковості підприємства, можливості сплачувати податки та накопичувати кошти для оновлення основних засобів та модернізації, належать: обсяг реалізованої води чи наданих послуг, собівартість послуг з централізованого водопостачання та водовідведення, тарифи на централізоване водопостачання та водовідведення, кредиторська та дебіторська заборгованість підприємств, загальна сума чистого доходу від реалізації послуг, сума чистого прибутку спрямовано на капітальні інвестиції, сума податків перерахованих до місцевого бюджету, сума додаткових державних чи приватних інвестицій залучених на модернізацію підприємства, показники ліквідності активів, підвищення вартості основних фондів. До технологічних показників та проведення модернізації підприємства з урахуванням інноваційних технологій, належать: втрати води під час транспортування, скид забруднених вод безпосередньо до природних водойм, кількість водопровідного насосного обладнання, і скільки з них потребує ремонту, кількість каналізаційного насосного обладнання, і скільки з них потребує ремонту, сумарна протяжність водопровідних мереж, відсоток ветхих та аварійних водопровідних мереж, які потребують заміни чи ремонту, сумарна протяжність каналізаційних мереж, відсоток ветхих та аварійних каналізаційних мереж, які потребують заміни чи ремонту, зносу та оновлення основних фондів, витрати електроенергії, показник обладнання житлових будинків приладами обліку спожитої води. До соціальних показників, як задоволення потреб споживачів у доступі та якості питної води, належать: охоплення населення послугами централізованого водопостачання та водовідведення міст, забезпечення споживачів послугами цілодобового водопостачання, відповідність реалізованої води стандартам якості питної води, розмір відрахувань на фінансування соціальних та екологічних програм, впровадження проектів інноваційного розвитку, наукових досліджень, розвиток міської інфраструктури [18].

Система водопостачання i каналізації міст являє собою складний комплекс споруд i будов, експлуатація яких потребує систематичного проведення технічних, економічних і організаційних заходів, оскільки від правильного вирішення задач, що пов'язані з їх проведенням, залежить не тільки благоустрій міста, але й нормальне життя населення і робота промислових підприємств. Навіть ідеально запроектована, побудована і налагоджена система водопостачання, каналізації згодом перестає забезпечувати постійні потреби споживачів. Тому, успішне управління роботою системи водопостачання і каналізації нерозривно пов'язане 3 
підготовкою висококваліфікованих кадрів, своєчасним впровадженням науково-технічних досягнень у виробництво, удосконалюванням господарського механізму [5, с.27].

Особливістю сфери водопостачання та водовідведення є належність їі суб'єктів господарювання до природних монополій та виробництво послуг соціального значення. Тому ефективність управління та функціонування у сфері водопостачання та водовідведення має враховувати ці фактори. Іншою особливістю $\epsilon$ належність більшості підприємств сфери до комунальної власності, що передбачає свої особливості 3 управління.

Система управління комунальними підприємствами здійснюється шляхом послідовної реалізації функцій з управління: планування, обліку, контролю та регулювання. Органи місцевого самоврядування укладають контракт 3 керівником комунального підприємства, частиною якого є певні фінансові показники, відповідно до яких визначається заробітна плата керівника. Як правило, за основу береться типова форма контракту 3 керівником підприємства державної власності [14]. При цьому, визначаються показники ефективності використання комунального майна і прибутку, що враховуються під час укладання контракту 3 керівником підприємства, зокрема: 1) Прибуток до оподаткування; 2) Інвестиції у розвиток виробничої сфери за рахунок власних та залучених коштів, у тому числі: капітальні інвестиції; модернізація, модифікація (добудова, дообладнання, реконструкція) основних фондів; приріст оборотних активів підприємства; 3) Сплата податків і зборів (обов'язкових платежів) до бюджетів; 4) Збори (внески) до державних цільових фондів, у тому числі на: обов'язкове державне пенсійне страхування; загальнообов'язкове державне соціальне страхування: - на випадок безробіття; - від нещасного випадку на виробництві та професійного захворювання, які спричинили втрату працездатності; - у зв'язку 3 тимчасовою втратою працездатності та витратами, зумовленими народженням та похованням; 5) Погашення податкового боргу, у тому числі розстроченого або відстроченого; 6) Повернення позик, кредитів та інших коштів, отриманих на поворотній основі 3 державного бюджету; 7) Відшкодування витрат місцевого бюджету, пов'язаних з виконанням гарантійних зобов'язань; Показники майнового стану підприємства: 8) Необоротні активи, у тому числі: основні фонди: - залишкова вартість; - знос; незавершене будівництво; нематеріальні активи; 9) Оборотні активи, у тому числі: запаси; дебіторська заборгованість; фінансові інвестиції; грошові кошти та їх еквіваленти; 10) Власний капітал; 11) Кредиторська заборгованість, у тому числі: за товари, роботи, послуги перед бюджетами; перед державними цільовими фондами з оплати праці [14].

Таким чином, можемо зробити висновок, що під ефективністю управління підприємствами водопостачання та водовідведення можна вважати рівень результативності діяльності підприємств, обчислений шляхом кількісної оцінки техніко-економічних результатів у сфері надання послуг водопостачання та водовідведення враховуючи внутрішні чинники: економічну, організаційно-кадрову, інноваційну, екологічну, технологічну складові та зовнішні: адаптивність, раціональне використання можливостей зовнішнього середовища, ефективність ризик-менеджменту, збалансованість інтересів усіх суб'єктів господарської діяльності у сфері водопостачання та водовідведення.

На державному рівні політика у сфері питної води та питного водопостачання зазначено базується на принципах: державного управління і регулювання відносин; пріоритетності питного водопостачання перед іншими видами спеціального водокористування; гарантованого першочергового забезпечення питною водою населення для забезпечення питних, фізіологічних, санітарно-гігієнічних та побутових потреб; раціонального використання питної води; науково обгрунтованого нормування якості питної води, нормативів ії споживання та формування тарифів на послуги централізованого водопостачання і водовідведення; наближення вимог національних стандартів на питну воду, питне водопостачання та водовідведення, технологій виробництва питної води, нормативів щодо очищення стічних вод, а також засобів вимірювання і методів оцінки до відповідних стандартів, нормативів, технологій, засобів і методів, прийнятих у ЄС; запобіжного характеру заходів щодо охорони джерел і систем питного водопостачання; дотримання оптимального балансу використання поверхневих і підземних вод для питного водопостачання; обов'язковості державної експертизи і оцінки експлуатаційних запасів підземних вод для питного водопостачання; обов'язковості оцінки впливу на довкілля і державної санітарно-епідеміологічної експертизи проектів господарської, інвестиційної та іншої діяльності, яка може негативно вплинути на стан джерел і систем питного водопостачання; економічного стимулювання раціонального використання питної води споживачами; невідворотності відповідальності у разі порушення законодавства у сфері; відшкодування збитків, завданих внаслідок порушення законодавства у сфері; забезпечення вільного доступу до інформації про якість питної води, стан джерел та систем питного водопостачання та водовідведення, порядку формування нормативів питного водопостачання та тарифів на послуги централізованого водопостачання і водовідведення; додержання єдиних правил, норм і стандартів усіма суб'єктами відносин у сфері питної води, питного водопостачання та водовідведення; ліцензування господарської діяльності із централізованого водопостачання та водовідведення; заборони відключення об'єктів питного водопостачання та централізованого водовідведення від системи енерго-, газо-, теплопостачання як об'єктів життєзабезпечення і стратегічного значення [22].

Іноземні експерти та науковці розглядають поняття «ефективне управління» в іншому контексті. Зокрема, з 1990-х років у словники політичної науки й практики державного управління міцно увійшов термін governance, а також Good Governance. Для країн, які розвиваються, забезпечення Good Governance є однією 3 обов'язкових умов отримання фінансової і технічної допомоги для їхнього національного розвитку. Ця концепція була розроблена й докладно описана передусім у дослідженнях національного розвитку 
африканських і азійських країн з метою їх ефективнішої та прискоренішої модернізації і полягала в наближенні принципів управління країною до стандартів розвинених західних націй (рекомендації Економічної та соціальної комісії ООН в Азії та Тихоокеанському регіоні) [2]. Погане управління (урядування) дедалі частіше вважають однією 3 першопричин проблем в наших суспільствах. Міжнародні фінансові інституції дедалі частіше видають допомогу або кредити лише за умови проведення реформ, які забезпечать «ефективне управління» та «хороше урядування». По суті це поняття означає процес (механізм) прийняття та реалізації рішень. Поняття «ефективне управління» та «хороше урядування» можна використовувати у різних контекстах, наприклад «корпоративне управління», «міжнародне урядування», «національне урядування» та «місцеве урядування». Хороше урядування має відповідати 8 основним принципам. Воно учасницьке, орієнтоване на консенсус, підзвітне, прозоре, відповідальне, результативне та ефективне, справедливе та всеосяжне, а також відповідає закону. Схема хорошого урядування зображена на рисунку 1.

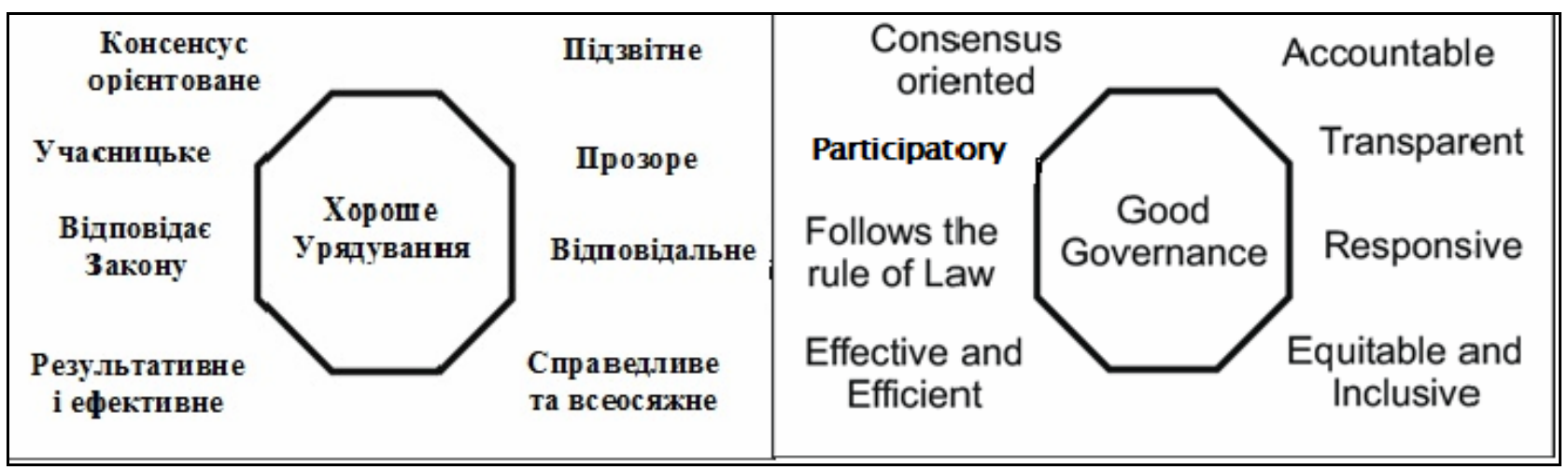

Рис. 1. Принципи хорошого урядування [2]

Слід зазначити, що самі розробники такої схеми вважають, що наведена схема хорошого урядування це ідеал, якого важко досягти в його цілості. Дуже мало країн та суспільств наблизилися до досягнення хорошого урядування у його цілості. Однак для того, щоб забезпечити сталий розвиток людства, слід працювати у напрямі цього ідеалу з метою втілити його в реальність [2].

Організація економічного співробітництва та розвитку (ОЕСР), (Organisation for Economic Co-operation and Development (OECD)) визначає поняття «Water Governance» водне врядування (управління водними ресурсами), як «коло політичних, інституційних та адміністративних правил, практик та процесів (формальних та неофіційних), за допомогою яких приймаються та впроваджуються рішення, зацікавлені сторони можуть формулювати свої інтереси та враховувати їх занепокоєння, а відповідальні особи несуть відповідальність. для управління водними ресурсами». Іншими словами, управління стосується ролі інституцій та відносин між організаціями та соціальними групами, які беруть участь у прийнятті рішень щодо води, як горизонтально між секторами, так і між міськими та сільськими районами та вертикально від місцевого до міжнародного рівнів. Управління - це засіб для досягнення мети, а тип управління повинен відповідати рівню ризику або масштабу проблеми, щоб відповідати політиці місцем. Управління повинно бути адаптивним, залежним від контексту та місця, щоб враховувати історичні та територіальні особливості та проблеми. Управління набагато ширше, ніж урядування, оскільки воно також має на меті включати приватний сектор, громадянське суспільство та широке коло зацікавлених сторін із часткою використання та управління водою. Реалізація політики на проблеми 3 водою буде життєздатною лише у тому випадку, якщо вона буде узгодженою та інтегрованою; якщо зацікавлені сторони належним чином будуть залучені; якщо існують чітко розроблені нормативні рамки; якщо є адекватна та доступна інформація; і якщо є достатня потужність, цілісність та прозорість [3].

Рамка індикаторів управління водним ресурсом ОЕСР має на меті підтримку впровадження Принципів ОЕСР щодо управління водними ресурсами, зображено на рисунку 2. У Принципах передбачено дванадцять обов'язкових критеріїв для ефективного управління водними ресурсами. Принципи застосовуються до загального циклу політики у сфері води та повинні здійснюватися систематично та всеосяжно. Принципи не розрізняють: функції управління водою (наприклад, питне водопостачання, каналізація, захист від повеней, якість води, кількість води, дощову та зливову); водокористування (наприклад, побутова, промисловість, сільське господарство, енергетика та навколишнє середовище); і право власності на управління водними ресурсами, ресурси та активи (наприклад, державні, приватні, змішані). 


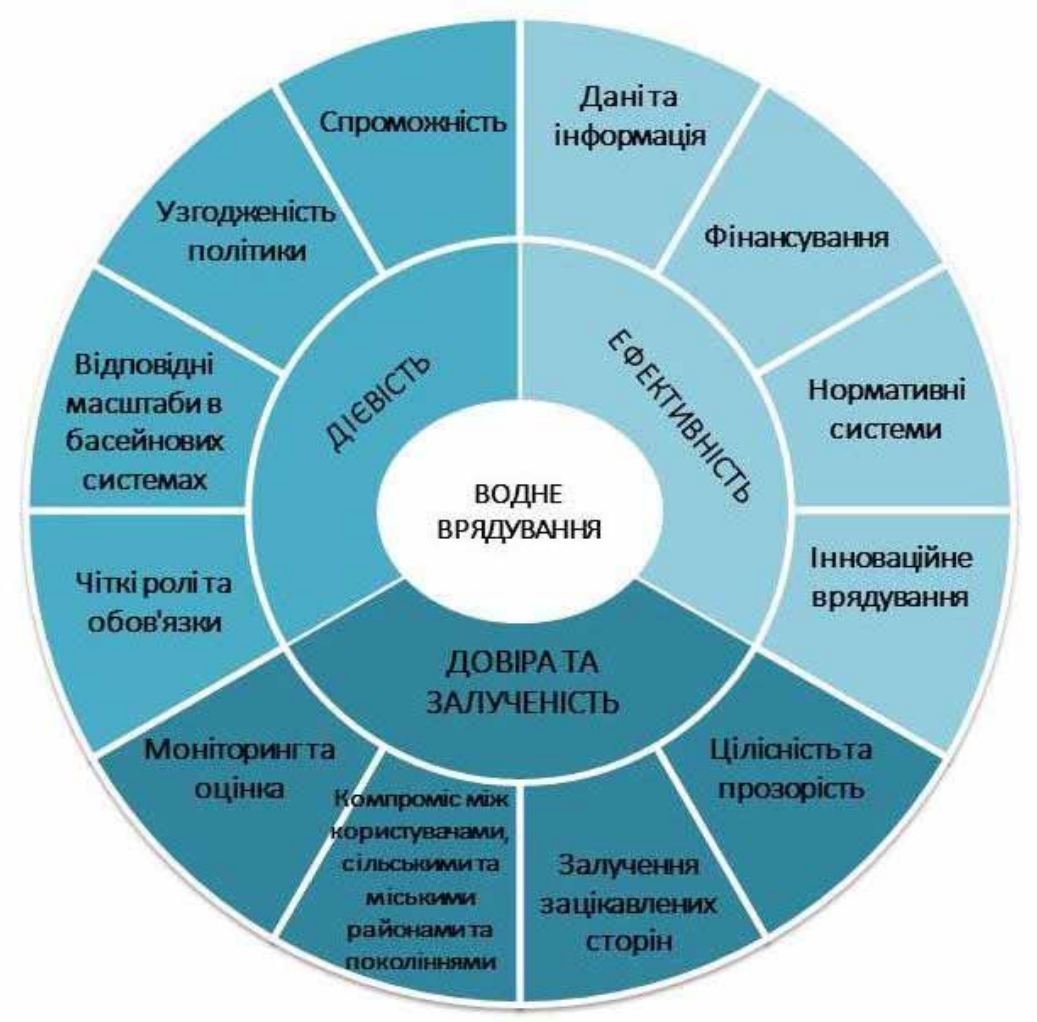

Рис. 2. Принципи ОЕСР щодо управління водними ресурсами [3]

Принципи водного врядування ОЕСР націлені на підтримку реалістичної та орієнтованої на досягнення цілей державної політики і спираються на три взаємопосилюючі і взаємодоповнюючі аспекти водного врядування: 1) Дієвість стосується вкладу врядування у визначення чітких цілей та цільових показників сталої водної політики на всіх рівнях державного управління, впровадження цих цілей політики та досягнення очікуваних цільових показників; 2) Ефективність стосується вкладу врядування для максимального збільшення вигоди від сталого управління водними ресурсами та добробуту з найменшими витратами для суспільства; 3 ) Довіра та участь стосуються вкладу врядування, спрямованого на зміцнення довіри громадськості та забезпечення участі зацікавлених сторін шляхом демократичної легітимності та справедливості для суспільства в цілому [3].

Безпосередньо для підприємств водопостачання та водовідведення Американське агентство охорони навколишнього природного середовища велика кількість основних асоціацій водного сектору, запропонували підхід, розроблений лідерами водного сектору для управління у сфері водопостачання та водовідведення Effective Utility Management (A Primer for Water and Wastewater Utilities) [1]. Цей підхід базується на десяти атрибутах ефективного управління послугами у сфері водопостачання та водовідведення та п'яти принципах успішного управління - відомих як Ефективне управління утилітами (EUM). Наразі EUM $\epsilon$ найбільш широко визнаною програмою управління послугами водопостачання та водовідведення в розвинутих країнах. EUM називають базовим документом для розвитку будь-якого підприємства водопостачання та водовідведення до ефективних та стійких операцій. Десять атрибутів та п'ять принципів ефективного управління у сфері водопостачання та водовідведення схематично зображено на рисунку 3.

До десяти атрибутів належать: 1) Якість продукції: має відповідати нормативним вимогам та вимогам надійності; направлена на потребу споживачів; направлена на вирішення питань охорони здоров'я та екологічних потреб; 


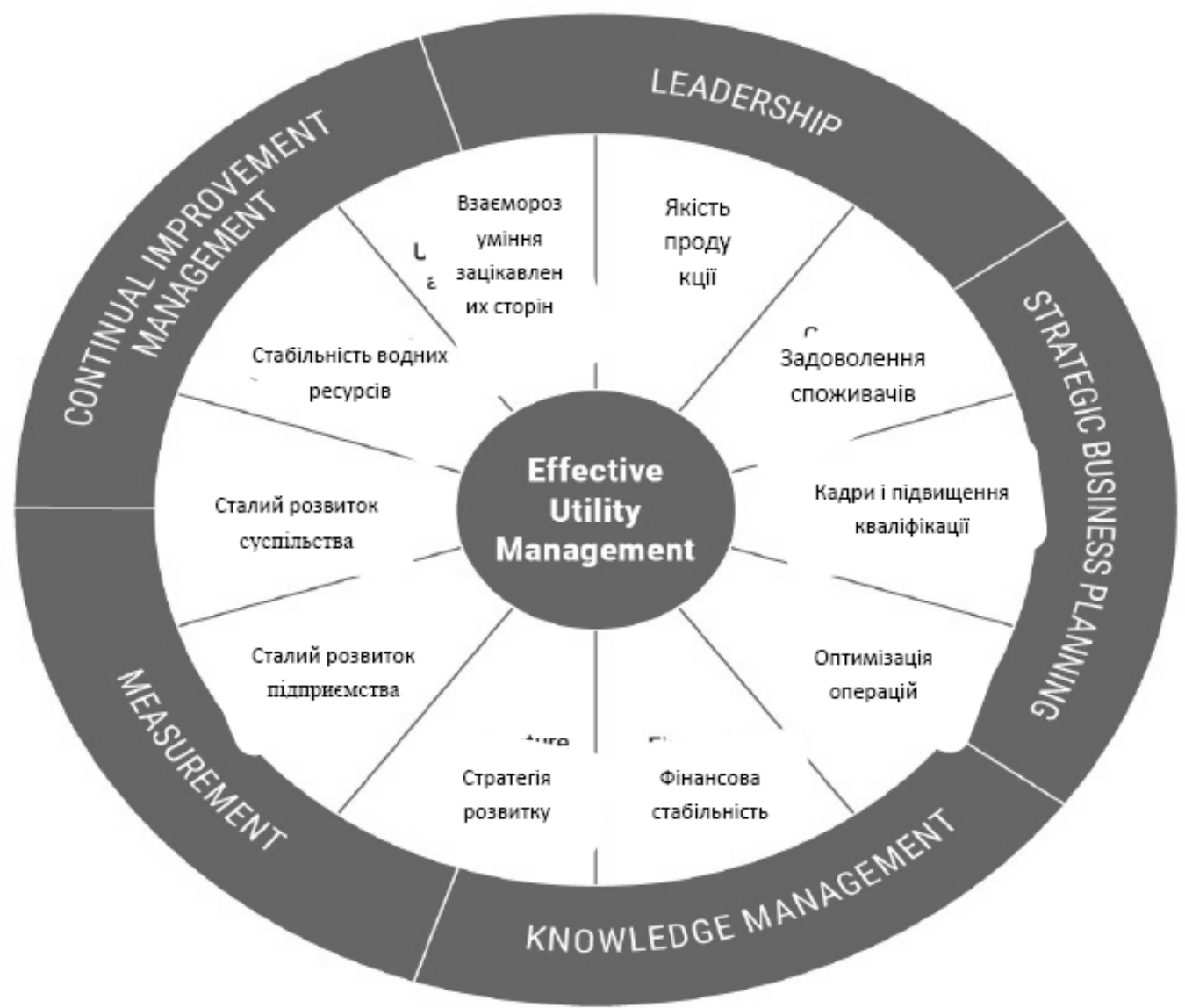

Рис. 3. Десять атрибутів ефективного управління у сфері водопостачання та водовідведення та п'ять принципів успішного управління

2) Задоволення споживачів: мінімізація скарг споживачів; необхідність досягнути цільового рівня надання послуг споживачам; досягнення позитивного сприйняття споживачів; забезпечення ефективного обслуговування споживачів; 3) Кадри та підвищення кваліфікації: підбір та збереження відповідних кадрів; вирішення питання спадкоємності кадрів; підвищення кваліфікації; 4) Оптимізація оперативної діяльності: постійне вдосконалення діяльності; мінімізація використання ресурсів та втрат від щоденних операцій; 5) Фінансова стабільність: прийняття надійного фінансового плану; забезпечення фінансової незалежності; ефективне управління фінансами; 6) Стратегія розвитку інфраструктурних проектів: розробка та реалізація програми управління активами; підтримка інформації про активи та витрати; прийняття рішень на основі системи управління ризиками; 7) Сталий розвиток підприємства: впровадження оцінки ризиків у процес прийняття рішень; здійснення заходів щодо зменшення ризиків; підтримка стійкості працівників; 8) Сталий розвиток суспільства: стабільність проектів інфраструктури; природнє середовище; економічна міцність; соціальна справедливість; 9) Стабільність водних ресурсів: досягнення достатності водопостачання; скорочення некомерційного водопостачання; забезпечення водозбереження; досягнення надійності водопостачання; 10) Взаєморозуміння зацікавлених сторін: ідентифікація зацікавлених сторін; план залучення зацікавлених сторін; стратегія залучення органів нагляду; програма взаємодії зі ЗМI; система оцінки ефективності підтримки зацікавлених сторін [1].

Принципи ефективного управління працюють на результат, окреслений в атрибутах, i можуть допомогти інтегрувати зусилля з удосконалення програми в межах атрибутів: 1) Лідерство (Leadership). Керівництво повинно відповідати як внутрішнім організаційним, так і більш широким загальним вимогам громади. Це важливо для ефективного управління комунальними послугами, особливо в контексті провідних та надихаючих змін в організації та в іiї оточуючому співтоваристві. «Лідерство» відноситься як до осіб, так і до команд, які забезпечують стійку і щоденну безперервність управління підприємством. Ефективне управління встановлює та передає довгострокове бачення організації та втілює прихильність до вироблення культури організації, допомагаючи вкорінювати методи для досягнення бачення корисності у щоденній діяльності підприємства. Керівники несуть відповідальність за активну взаємодію із зацікавленими сторонами та органами, які приймають рішення, сприяють використанню корисності як цінного, компетентного та надійного екологічного розпорядника та активів громади та співпрацюють із зовнішніми партнерами. 2) Стратегічне бізнес планування (Strategic Business Planning). Стратегічне бізнес-планування спрямовує та допомагає досягти балансу та згуртованості через десять атрибутів. Стратегічний бізнес-план забезпечує основу для прийняття рішень: оцінка сучасних умов та проведення сильних, слабких сторін, можливостей та загроз (SWOT-аналіз); характеристика можливих та ймовірних майбутніх умов; оцінка основних причин та наслідків майбутніх умов; 
встановлення бачення, цілей, стратегій та основних організаційних цінностей. Успішний стратегічний бізнесплан $є$ динамічним та адаптованим, що дозволяє підприємствам скористатися новими можливостями. Ефективний стратегічний план відображає конкретні кроки впровадження, які змістять підприємство 3 його поточного рівня продуктивності до досягнення нового бачення. Стратегічний бізнес-план має постійно моніторитись та переглядатись. 3) Управління знанням (Knowledge Management). Управління знаннями має вирішальне значення для забезпечення надійних операцій підприємства, що охоплює стандартні операційні процедури, управління людськими ресурсами та бізнес-системами, інтеграцію та використання даних операційних систем для підтримки надійних операцій та постійного вдосконалення через десять атрибутів. Забезпечуючи, щоб процеси були добре задокументовані, встановлюючи та регулярно оновлюючи стандартні операційні процедури та створюючи спільні знання серед різних категорій працівників, підприємство може ефективно реагувати на неминучі втрати знань, спричинені плинністю кадрів. Ефективна система управління знаннями гнучка до використання новітніх технологій і повинна постійно оновлюватися. Автоматизовані системи та можливості інтеграції / управління даними є важливим аспектом ефективного управління. 4) Оцінка (Measurement). Оцінка має значення для зусиль щодо вдосконалення управління, пов'язаних з атрибутами, і $є$ основою успішного постійного вдосконалення управління та стратегічного бізнес-планування. Система оцінювання служить багатьом життєво важливим цілям, включаючи фокусування уваги на ключових питаннях, уточнення очікувань, полегшення прийняття рішень, підтримку навчання та вдосконалення, встановлення та підтримання підзвітності та, головне, ефективне спілкування всередині та зовні. С важливе правила в управлінні: «Якщо ви не можете його оцінити, ви не можете його покращити». 5) Постійне вдосконалення управління (Continual Improvement Management). Постійне вдосконалення управління відіграє центральну роль в ефективному управлінні підприємствами і має вирішальне значення для досягнення прогресу в атрибутах. Постійне вдосконалення управління підтримується аналізом розбіжностей, встановленням стандартних операційних процедур, внутрішнім аналізом тенденцій та зовнішнім бенчмаркінгом, де це доречно, переглядом та прийняттям кращих практик та іншими інструментами постійного вдосконалення [4].

Висновки 3 дослідження. Підприємства водопостачання та водовідведення працюють постійно і безперервно, забезпечують населення життєвоважливими послугами, підтримують життєздатність громад, природного середовища та економіки. При цьому, підприємства працюють в умовах широкого спектру внутрішніх та зовнішніх складних проблем від технічного стану основних фондів до регуляторної державної політики. Для організації належної роботи підприємства водопостачання та водовідведення, вирішення поточних та майбутніх проблем потрібні знання, досвід, доцільний та проактивний набір підходів. Ефективність управління та організації роботи підприємства водопостачання та водовідведення може бути оцінена шляхом визначення відповідних показників ефективності. Враховуючи відсутність вітчизняних стандартів та принципів ефективного управління підприємствами водопостачання та водовідведення, окрім показників ефективності використання комунального майна і прибутку, до уваги можна взяти розроблені провідними міжнародними водними асоціаціями атрибути та принципи ефективного управління.

\section{Список літератури.}

1. Effective Utility Management: A Primer for Water and Wastewater Utilities, 2017. URL: https://www.epa.gov/sustainable-water-infrastructure/effective-utility-management-primer-water-and-wastewaterutilities (дата звернення: 15.07.2018).

2. Hukka J.J., Katko T.S. Water Privatisation Revisited. Panacea or Pancake? 2003. URL: https://www.ircwash.org/sites/default/-files/Hukka-2003-Water.pdf (дата звернення: 15.07.2018).

3. OECD Water Governance Indicator Framework, 2018. URL: https://www.oecd.org/cfe/regionalpolicy/oecd-water-governance-indicator-framework.htm (дата звернення: 15.07.2018).

4. Utility Management: Effective Utility Management The Ten Attributes of Effective Utility Management. URL: $\quad$ http://www.waterrf.org/knowledge/utility-management/FactSheets/UtilityMgmt_EUM_FactSheet.pdf (дата звернення: 15.07.2018).

5. Агаджанов Г.К. Економіка водопровідно-каналізаційних підприємств: навч. посіб. 2-е вид., перероб. та доп. - Х.: ХНАМГ. - 2010. - 392 с.

6. Атаманчук Г.В. Теория государственного управления: курс лекций. 3-е изд.,доп. - М.: Изд-во ОМЕГА-Л. - 2005. - 584 с.

7. Білюк А.В. Оцінка ефективності діяльності комунальних підприємств // Матеріали П'ятнадцятої всеукраїнської практично-пізнавальної конернет конені.

URL: http://naukam.triada.in.ua/index.php/konferentsiji/45-p-yatnadtsyata-vseukrajinska-praktichno-piznavalna-internetkonferentsiya/277-otsinka-efektivnosti-diyalnosti-komunalnikh-pidpriemstv (дата звернення: 15.07.2018).

8. Коврижных И.В. Анализ и оценка эффективности управления в организации. - Барнаул: АФ СибАГС. - 2006. - 86 с.

9. Кравченко В. О. Менеджмент: навч. посібн. - Одеса: Атлант. - 2013. -165 с.

10. Мескон М., Альберт М., Хедоури Ф. Основы менеджмента. - М.: Вильямс. - 2007. - 672 с.

11. Павленко И.Г. Подходы к определению экономической сущности понятия «эффективность»// Экономика и управление. 2006. № 1. С. 35-38.

12. Приживара С. Управління як специфічний вид діяльності // Державне будівництво - 2012. - № 1 . URL: http://www.kbuapa.kharkov.ua/e-book/db/2012-1/doc/1/07.pdf (дата звернення: 15.07.2018). 
13. Про питну воду, питне водопостачання та водовідведення: Закон від 10.01.2012 р. № 2918-III. База даних «Законодавство України». URL: http://zakon3.rada.gov.ua/laws/show/2918-14 (дата звернення: 15.07.2018).

14. Про Типову форму контракту з керівником підприємства, що є у державній власності: постанова Кабінету Міністрів України від 02.08.1995 №597. База даних: «Законодавство України». URL: https://zakon.rada.gov.ua/-laws/show/597-95-\%D0\%BF (дата звернення: 15.07.2018).

15. Рац О.М. Визначення сутності поняття «ефективність функціонування підприємства» // Економічний простір: Зб. наук. праць. - 2008. №15. - С. 275-285.
16. Рудьман
Я.В.
Эффективность
управления
предприятием,
2013.
URL:

http://conference.be5.biz/r2013/4466.htm (дата звернення: 15.07.2018)

17. Рульєв В.А., Гуткевич С.О. Менеджмент. - К.: Центр учбової літератури, 2011. - 312 с. URL: http://www.dut.edu.ua/uploads/1_1171_86364415.pdf (дата звернення: 15.07.2018).

18. Сугак Т.М. Оцінка ефективності діяльності підприємств сфери централізованого водопостачання та водовідведення // Ефективна економіка. - 2018. - № 2. URL: http://www.economy.nayka.com.ua/?op=1\&z=6771 (дата звернення: 15.07.2018).

19. Федулова С.О. Економіка підприємств водопостачання та водовідведення: навч. посіб. - Дніпро: ДВНЗ УДХТУ. - 2017. - 300 c. URL: https://udhtu.edu.ua/wp-content/uploads/2019/03/Ekonomika-pidpr.-vodopid.ta-vodovid_Pivovarov_Fedulova.pdf (дата звернення: 15.07.2018).

20. Філіппова О.С. Сутнісна характеристика ефективності діяльності підприємств житловокомунального господарства // Економіка та управління, №1. -2012. - C.129-135 URL: http://kafmen.ru/library/compilations_vak/eiu/2012/1-/p_129_135.pdf (дата звернення: 15.07.2018).

21. Шатун В.Т. Основи менеджменту: навч. посібн. - Миколаїв: Вид-во МДГУ ім.Петра Могили. 2006. - 376 c. URL: http://lib.chdu.edu.ua/pdf/-posibnuku/191/1.pdf (дата звернення: 15.07.2018).

22. Щеглова О.Ю., Судакова О.І., Лаже М.В. Ефективність управління підприємством та підходи до ії визначення // Науковий вісник Ужгородського національного університету. - 2017. № 12. - С. 186-190.

\section{References.}

1. Effective Utility Management: A Primer for Water and Wastewater Utilities, 2017, [Online], available at: https:/www.epa.gov/sustainable-water-infrastructure/effective-utility-management-primer-water-and-wastewaterutilities (Accessed 15 July 2019).

2. Hukka J.J., Katko T.S. Water Privatisation Revisited. Panacea or Pancake? 2003, [Online], available at: https:/www.ircwash.org/sites/default/-files/Hukka-2003-Water.pdf (Accessed 15 July 2019).

3. OECD Water Governance Indicator Framework, 2018, [Online], available at: https://www.oecd.org/cfe/regional-policy/oecd-water-governance-indicator-framework.htm (Accessed 15 July 2019).

4. Utility Management: Effective Utility Management The Ten Attributes of Effective Utility Management,
[Online], $\quad$ available management/FactSheets/UtilityMgmt_EUM_FactSheet.pdf (Accessed 15 July 2019).

5. Ahadzhanov, H.K. (2010), Ekonomika vodoprovidno-kanalizatsiinykh pidpryiemstv [Economics of water supply and sewerage companies], 2nd ed., KhNAMH, Kharkiv, P. 392.

6. Atamanchuk, G.V. (2005), Teorija gosudarstvennogo upravlenija: kurs lekcij [Theory of public administration: lecture course], 3rd ed., Izd-vo OMEGA-L, Moscow, Russia, P.584.

7. Biliuk, A.V. "Estimation of efficiency of activity of communal enterprises", Materials of the Fifteenth AllUkrainian Practical-Cognitive Internet Conference [Online], available at: http://naukam.triada.in.ua/index.php/konferentsiji/45-p-yatnadtsyata-vseukrajinska-praktichno-piznavalna-internetkonferentsiya/277-otsinka-efektivnosti-diyalnosti-komunalnikh-pidpriemstv (Accessed 15 July 2019).

8. Kovrizhnyh, I.V. (2006), Analiz $i$ ocenka jeffektivnosti upravlenija v organizacii [Analysis and assessment of management effectiveness in the organization], AF SibAGS, Barnaul, Russia, P. 86.

9. Kravchenko, V. O. (2013), Menedzhment [Management], Atlant, Odesa, Ukraine, P. 165.

10. Meskon, M. Al'bert, M. and Hedouri F. (2007), Osnovy menedzhmenta [Fundamentals of Management], Vil'jams, Moscow, Russia, P. 672.

11. Pavlenko, I.G. (2006), "Approaches to the definition of the economic essence of the concept of "efficiency"", Jekonomika i upravlenie, vol. 1, pp. 35-38.

12. Pryzhyvara, S. (2012), "Management as a specific kind of dyalnosty", Derzhavne budivnytstvo, vol. 1, [Online], available at: http://www.kbuapa.kharkov.ua/e-book/db/2012-1/doc/1/07.pdf (Accessed 15 July 2019).

13. The Verkhovna Rada of Ukraine (2012), The Law of Ukraine " On Drinking Water, Drinking Water Supply and Drainage", available at: http://zakon3.rada.gov.ua/laws/show/2918-14 (Accessed 15 July 2019).

14. Cabinet of Ministers of Ukraine (1995), Resolution of the Cabinet of Ministers of Ukraine " On the Typical Form of the Contract with the Head of the State-Owned Enterprise", [Online], available at: https://zakon.rada.gov.ua/-laws/show/597-95-\%D0\%BF (Accessed 15 July 2019).

15. Rats, O.M. (2008), "Defining the essence of the concept of "efficiency of the enterprise"", Ekonomichnyi prostir: Zb. nauk. prats, vol.15, pp. 275-285.

16. Rud'man, Ja.V.(2013), "The effectiveness of enterprise management", [Online], available at: http://conference.be5.biz/r2013/4466.htm (Accessed 15 July 2019). 
17. Ruliev, V.A. and Hutkevych, S.O. (2011), Menedzhment [Management], Tsentr uchbovoi literatury, Kyiv, Ukraine, P.312, [Online], available at: http://www.dut.edu.ua/uploads/1_1171_-86364415.pdf (Accessed 15 July 2019).

18. Sugak, T. M. (2018), "Estimation of efficiency of the activity of enterprises ofcentral water supply and sewerage", Efektyvna ekonomika, [Online], vol. 2, available at: http://www.economy.nayka.com.ua/?op=1\&z=6771 (Accessed 15 July 2019).

19. Fedulova, S.O. (2017), Ekonomika pidpryiemstv vodopostachannia ta vodovidvedennia [Economics of Water Supply and Drainage Enterprises], DVNZ UDKhTU, Dnipro, Ukraine, P. 300, [Online], available at: https://udhtu.edu.ua/wp-content/uploads/2019/03/Ekonomika-pidpr.-vodopid.-ta-vodovid_Pivovarov_Fedulova.pdf (Accessed 15 July 2019).

20. Filippova, O.S. (2012), "Essential characteristics of efficiency of activity of the enterprises of housing and communal services", Ekonomika ta upravlinnia, vol. 1, pp.129-135, [Online], available at: http://kafmen.ru/library/compilations_vak/eiu/2012/1-/p_129_135.pdf (Accessed 15 July 2019).

21. Shatun, V.T. (2006), Ossnovy menedzhmentu [Fundamentals of Management], Vyd-vo MDHU im.Petra Mohyly, Mykolaiv, Ukraine, P.376, [Online], available at: http://lib.chdu.edu.ua/pdf/-posibnuku/191/1.pdf (data zvernennia: 15.07.2018).

22. Shchehlova, O.Yu. Sudakova, O.I. and Lazhe, M.V. (2017), "Efficiency of enterprise management and approaches to its definition", Naukovyi visnyk Uzhhorodskoho natsionalnoho universytetu, vol. 12, pp. 186-190.

Стаття надійшла до редакиії 02.08.2019 p. 